\title{
PEDAGOŠKO-ANDRAGOŠKI DNEVI 2021
}

Pedagoško-andragoške dneve (PAD) smo v letu 2021 na Oddelku za pedagogiko in andragogiko Filozofske fakultete Univerze v Ljubljani organizirali nekoliko kasneje, ne v januarju, temveč v septembru. Vzrok za zamik je bila pandemija covida-19, saj dogodka $\mathrm{v}$ januarju nismo mogli izpeljali v živo, medtem ko nam je septembra to vendarle uspelo. Organizacijski odbor PAD 2021 smo sestavljali: dr. Monika Govekar-Okoliš - predsednica ter člani Nina Breznikar, dr. Matej Urbančič in dr. Marko Radovan. Programski odbor pa so poleg dr. Monike Govekar-Okoliš sestavljali dr. Jana Kalin, dr. Nives Ličen in dr. Marjeta Šarić. PAD 2021 je vključeval pet plenarnih predavanj, tri vzporedne diskusijske skupine, v katerih so potekale predstavitve primerov dobrih praks, in fotografsko razstavo na Filozofski fakulteti. Letošnja novost PAD 2021 je bil tudi predkonferenčni dogodek, Študentski PAD (šPAD). Študentje Oddelka za pedagogiko in andragogiko so v sredo, 15. septembra 2021, prvič izvedli Študentski pedagoško-andragoški dan. Predstavili so šest raziskovalnih in seminarskih nalog o raznolikih temah (šolskem svetovalnem delu, učenju odraslih z motnjo v duševnem razvoju, transformativnem učenju ob žalovanju, izobraževanju zaporniških delavcev, izobraževanju odraslih o zborovskem petju ter predkariernem razvoju). Temu je sledila skupinska diskusijska delavnica. Za zaključek pa je bila v popoldanskem času na daljavo organizirana tudi kavarna doktorskih študentov oddelka z gostjo Katjo Lihtenvalner, ki jo je vodila dr. Nives Ličen.

Osrednji del Pedagoško-andragoških dnevov pa se je odvil v četrtek, 16. septembra 2021, na Filozofski fakulteti Univerze v Ljubljani (39. izvedba). Naslovna tema srečanja je bila Inovativna učna okolja in izkušnje iz karantene. Posebna pozornost se je tokrat namenila razmislekom, kako je pandemija covida-19 vplivala na pedagoge in andragoge ter na njihovo vzgojno-izobraževalno delo. Poskušali smo odgovoriti na vprašanja, ali se je spremenila njihova praksa poklicnega oz. strokovnega delovanja ter kako in koliko so se učili ob izkušnji dela na daljavo. Zanimalo nas je tudi, kako so pedagogi in andragogi doživljali ta čas in kako so se soočali z ovirami (npr. z nezmožnostmi soočanja z nepredvidljivimi težavami, strahom, nizkimi pričakovanji in motivacijo). Eno izmed ključnih vprašanj pa je bilo tudi, ali so spremenjene razmere dela pomembno spodbujale oz. ovirale poklicni razvoj pedagoga in andragoga.

$\mathrm{Na}$ začetku PAD sta dekan Filozofske fakultete Univerze v Ljubljani dr. Roman Kuhar in predstojnica Oddelka za pedagogiko in andragogiko dr. Klara Skubic Ermenc v uvodnem nagovoru poudarila pomen PAD in njegovo aktualno tematiko. $\mathrm{O}$ formalnostih poteka PAD je spregovorila dr. Monika Govekar-Okoliš, ki je bila moderatorka plenarnega dela predavanj. 
Prvo plenarno predavanje sta imeli dr. Jana Kalin in gostujoča predavateljica z Andragoškega centra Slovenije dr. Petra Javrh. Naslov njunega predavanja je bil Možnosti učenja drug od drugega na delovnem mestu v času pandemije. Povedali sta, kako se je v času pandemije poklicno življenje učiteljev močno spremenilo, saj so se morali čez noč prilagoditi na poučevanje na daljavo. Ob tem sta poudarili, da je drugačen način dela terjal tudi spremembe v poklicnem usposabljanju učiteljev. Izzivi, ki jih je prinesla epidemija na področju poklicnega razvoja učiteljev, so bili predvsem pomanjkanje znanja o informacijsko-komunikacijski tehnologiji na strani učiteljev, fizična izolacija od kolegov, osebne težave pri spopadanju z epidemijo ter pomanjkanje motivacije za učenje. Ugotovitve raziskave, ki sta jo predstavili, so pokazale, da so ovire pri poklicnem razvoju v času epidemije postavljali tudi nizke predstave o sebi in lastnih zmožnostih za učenje, nizka pričakovanja, nezmožnost soočanja z nepredvidljivimi težavami, strah in izogibanje tveganju. Izpostavili sta tudi, da sta še zlasti med epidemijo covida-19 pomemben dejavnik spodbujanja ali oviranja poklicnega razvoja bili tudi klima in podpora institucije, $\mathrm{v}$ kateri je posameznik deloval. Naj ob tem poudarimo spodbudne rezultate raziskave Kalin idr. (2021), v kateri so ravnatelji potrdili, da je kriza strokovne delavce in ravnatelje tesno povezala. $\mathrm{V}$ času dela od doma so mnoge strokovne delovne skupine okrepile sodelovanje in učenje drug $\mathrm{z}$ drugim ter preizkušanje drugačnih pristopov. S tem so zelo različne praktične probleme dela na daljavo idr. reševale s kolegialnim prenašanjem znanja med seboj. Ključna ugotovitev plenarnega predavanja je bila, da je učenje na delovnem mestu odvisno od treh pogojev: medsebojnega zaupanja, podpore zunaj in znotraj institucije ter izzivov. Prepletanje vseh treh vidikov pa predstavlja način in priložnost učiteljev za poklicno rast z močnim potencialom.

Drugo plenarno predavanje z naslovom Soočanje učiteljev s čustvenimi izzivi pri delu na daljavo je imela dr. Marjeta Šarić. S predstavitvijo rezultatov aktualnih študij je postavila $\mathrm{v}$ ospredje, kako pomembno je razumevanje in uravnavanje čustvenih odzivov učiteljev med pandemijo. Spremembe v načinu dela so namreč pri učiteljih sprožile različne čustvene odzive, pri čemer pa je soočanje s čustvi odvisno od treh dejavnikov: individualne psihološke perspektive, čustvene fleksibilnosti in socialnokonstruktivistične perspektive. Iz predstavljenih podatkov raziskav je izpeljala načela za uspešno soočanje s čustvi pri delu, pri čemer je poudarila dva ključna vidika: 1) možne vire moči in oblike podpore za ohranjanje temeljnega duševnega ravnotežja ter 2) vlogo skupnosti, znotraj katere se čustva porajajo, prenašajo, uravnavajo in tudi razpustijo. Pri tem je opozorila, da sta pri konstruktivnem soočanju s čustvenimi stresorji ključna elementa soodvisnost in prepletenost obeh vidikov.

Na naslovno vprašanje Covid-19: zgolj izkušnja ali točka preloma v profesionalnem razvoju učitelja? je v naslednjem plenarnem predavanju odgovarjala dr. Danijela Makovec Radovan. Predstavila je pomen učiteljevega profesionalnega razvoja in poudarila, kako se učitelj izpopolnjuje na strokovnem področju, kako dopolnjuje svoje pedagoške kompetence in ravnanja ter se pri tem tudi osebnostno spreminja. Povedala je tudi, da je ta proces močno vpet $\mathrm{v}$ kulturno in družbeno dogajanje ter da učiteljevega profesionalnega razvoja 
ne moremo obravnavati posplošeno, ampak vedno terja individualen pristop. Na profesionalni razvoj pa pomembno vplivajo učiteljeva prepričanja, pričakovanja o svojem poklicu in vlogi, kot tudi pričakovanja, ki jih imajo neposredno do učitelja njegovi učenci, vodstvo šole, sodelavci in starši. To se je še posebej izrazilo med epidemijo covida-19, ko se je bilo treba hitro prilagoditi novim načinom dela, spremembam, doživljanju stisk, nemoči idr. Vse to je vplivalo na delo učiteljev in njihov profesionalni razvoj. Učitelji so ob tem doživeli karierni šok, ki je v njih sprožal vprašanje: Kaj zdaj to pomeni zame kot učitelja? Predavateljica je izpeljala tri nauke, ki se jih lahko naučimo iz obdobja pandemije: 1) odziv posameznika na spremembe $\mathrm{v}$ profesionalnem razvoju učitelja je odvisen od prepletanja kontekstualnih in individualnih dejavnikov, pri čemer je ključno tudi širše ozaveščanje o kariernem šoku in kako se z njim spopadati; 2) treba je analizirati kratkoročne in dolgoročne učinke kariernega šoka in 3) negativni karierni šok lahko spodbudi tudi pozitivne izide, saj je omogočil, da so se učitelji hitro odzvali, se učili novih pristopov učenja na daljavo, po šolah pa se je povečalo tudi kolegialno učenje. Glavna ugotovitev plenarnega predavanja je bila, da je bil čas epidemije covida-19 priložnost za razvoj številnih novih znanj. Ob tem je predavateljica poudarila, da bi morala vodstva šol analizirati vse nevralgične točke iz časa epidemije, hkrati pa bi morala tudi država nameniti več sredstev za razvijanje in spodbujanje profesionalnega razvoja učiteljev in za razvoj možnosti kombiniranih oblik dela $v$ šolah, kjer je to seveda možno in smiselno.

Četrto plenarno predavanje z naslovom Tri pandemične lekcije o vzgoji in izobraževanju je imel gostujoči predavatelj dr. Tomaž Grušovnik s Pedagoške fakultete Univerze na Primorskem. Kot prvo lekcijo je navedel, da se je z ustavitvijo javnega življenja in vzpostavitvijo šolanja na daljavo pomembnost vzgojno-izobraževalnih institucij v družbi povečala. Širša javnost je namreč šele ob izkušnji šolanja lastnih otrok doma odkrito priznala, kako nepogrešljiv je lik učitelja. Da so vzgojno-izobraževalne institucije pomemben del družbene infrastrukture, se je pokazalo tudi pri zagotavljanju enakih možnosti izobraževanja, saj je bila kakovost šolanja na daljavo zelo odvisna od izobraženosti staršev. Druga lekcija, ki jo je predstavil predavatelj, je bila, da se vloga vzgojno-izobraževalnih institucij ne prepoznava le $\mathrm{v}$ prenašanju informacij, temveč predvsem $\mathrm{v}$ izgrajevanju ustreznega spoznavnega značaja in krepitvi spoznavnih vrlin pri posamezniku. Slednje je namreč bistveno, da se je posameznik sposoben soočati s svetom lažnih novic, postresničnostjo in teorijami zarot, ki so se v času pandemije še okrepile. Tretja lekcija o vzgoji in izobraževanju v času pandemije pa je povezana s samim izobraževanjem na daljavo. Izkušnje so pokazale, da izobraževanje na daljavo ponuja tudi prednosti, zlasti razvoj novih didaktičnih gradiv, izboljšanje znanja na področju uporabe informacijsko-komunikacijske tehnologije ter povečanje dostopnosti izobraževanja in sodelovanja večjega števila izvajalcev in udeležencev. Opozoril je tudi na poglede določenega segmenta populacije, ki bi se rada vrnila zgolj k t. i. tradicionalnim oblikam učenja in poučevanja. S tem se odpira konflikt na področju vzgoje in izobraževanja, ki bi lahko zaviral uvajanje novih oblik izobraževanja na daljavo, zlasti zaradi pravnoformalnih vidikov, ki urejajo to področje in so nastali pred epidemijo covida-19. Predavatelj je zato še posebej poudaril pomen pedagogike kot znanstvene discipline ter vzgoje in izobraževanja nasploh, ki mora prispevati $\mathrm{k}$ formaciji 
aktivnega državljana, k razvijanju njegovih osebnih potencialov ter poskrbeti, da bo postal radoveden, pogumen in kritičen posameznik.

Zadnje plenarno predavanje pa je imelo naslov Vzgoja $v$ času pandemije zahteva izgradnjo inovativnih učnih okolij - primer vzgoje z umetnostjo. Dr. Robi Kroflič, dr. Petra Štirn Janota in Darja Štirn, obe predavateljici prihajata z Zavoda Petida, so uvodoma izpostavili, kako se je šolanje v času izobraževanja na daljavo spremenilo v obliko usmerjenega učenja na domu, hkrati pa so poudarili, da se je s potezami prosvetne politike krepila tudi negativna podoba mladostnikov $\mathrm{v}$ javnem prostoru. Mlade so naslavljali kot skupino neodgovornih ljudi, ki ne upoštevajo zaščitnih ukrepov in prispevajo k širitvi virusa. Opozorili so, da se je premalo pozornosti posvečalo pastem digitaliziranega sveta, zlasti (dez) informacijam. Vse to pa je povzročilo, da je zaznati povečanje socialnih in psihičnih stisk, osamljenosti, (samo)destruktivnega vedenja in celo samomorilnih misli med mladimi. V nadaljevanju predavanja so predstavili projekt SKUM (Razvijanje sporazumevalnih zmožnosti s kulturno-umetnostno vzgojo). Prikazali so, kako lahko vzgoja z umetnostjo vzpostavi tesen stik med pedagoškimi delavci, umetniki oz. kulturnimi institucijami in otroki/ mladostniki. Opisali so, kako so v vzgojno-izobraževalnih institucijah sodelujoče učitelje in umetnike pozvali, da najdejo načine za nadaljevanje projektov vzgoje z umetnostjo, tematiko projektov pa povežejo s problemi, ki jih otroci/mladostniki med pandemijo doživljajo kot zase najbolj pomembne. Kot izhodišče umetniške komunikacije so izbrali različne načine pripovedovanja in poslušanja zgodb. Izbrane tematike umetniških projektov so poglabljali z refleksijo otrok/mladostnikov o okoliščinah, v katerih so se znašli v času epidemije. Glavni namen je bil, da so poskušali otroke/mladostnike premakniti iz pasivnega položaja $\mathrm{v}$ aktivno držo okoljskega aktivizma in upora.

Po končanih plenarnih predavanjih so se udeleženci PAD razdelili v tri diskusijske skupine. Prvo skupino z naslovom Delovno mesto: prostor zaupanja, podpore, izzivov sta moderirali dr. Jana Kalin in dr. Petra Javrh. Udeleženci so si izmenjali izkušnje iz karantene o podpori in predvsem o izzivih, ki so se $\mathrm{v}$ času izobraževanja na daljavo pojavili na delovnem mestu. V skupini so sodelovali tako učitelji in svetovalni delavci iz osnovnih in srednjih šol kot tudi andragogi, izobraževalci odraslih in visokošolski učitelji. V diskusiji se je izkazalo, da je $\mathrm{v}$ času dela na daljavo strokovne delavce pestilo več problemov: pomanjkanje motivacije pri delu z učenci, ki imajo učne in vedenjske težave, soočanje $\mathrm{z}$ neznanjem pri uporabi različnih spletnih aplikacij in orodij, občutek sramu ob poskusih vzpostavitve zasilne komunikacije z učenci, starši, spoznanje o novem učenju ter uporabi različnih spletnih aplikacij in orodij ter problem pri spretnostih ločevanja delovnega od zasebnega okolja. Pri delu s študenti je bila zelo zahtevna hibridna oblika dela (pol študentov je bilo v predavalnici, pol na daljavo). Skozi čas se je motivacija študentov zmanjšala, saj študenti niso bili več tako aktivni, učitelji pa so se spraševali, kako naj predavajo, da bodo spodbudili študente k sodelovanju. Na drugi strani pa je bilo zaznati tudi podporo med učitelji, kolegi $\mathrm{v}$ aktivih, kjer je sodelovalo tudi vodstvo posamezne institucije. V veliko pomoč so bili medsebojno sodelovanje, svetovanje, podpora ter neformalni pogovori v spletnem okolju. Pokazalo se je, kako pomembno je bilo v času dela 
od doma znati uravnavati poklicne obveznosti z zasebnim življenjem, kar je bil za mnoge zelo stresen izziv.

Drugo diskusijsko skupino z naslovom Soočanje s čustvenimi izzivi na delovnem mestu $v$ času pandemije je moderirala dr. Marjeta Šarić. Namen diskusije je bil povezati obravnavano temo z osebnimi izkušnjami in jih izmenjati v skupini. V nadaljevanju so udeleženci na kratko povzeli osrednje teme diskusije. V ospredju je bilo, kako sta za soočanje s čustvi ob vračanju v »običajne razmere « po obdobju dela od doma potrebna čas in tudi sočutje do sebe, kako je pomembno zavedanje, da morda nismo enako produktivni ali hitri pri delu, kot smo bili vajeni od doma. To spoznanje nam lahko pomaga razumeti učence, dijake in študente ter se bolj senzitivno odzvati v odnosu do njih. Tudi oni potrebujejo čas, potrpežljivost in podporo, ko se vračajo v učilnice in predavalnice. Ugotovitev skupine je bila, da je s tem, ko je učitelj dovzeten za lastno ranljivost, lahko bolj odprt in dovzeten tudi za potrebe drugih. Poudarjena je bila Gogalova misel o učitelju kot človeku in da je njegovo ključno orodje prav njegova osebnost. To seveda vključuje vse razsežnosti, vključno z zavedanjem lastnega čustvenega dogajanja. $\mathrm{Ob}$ koncu razprave so se udeleženci dotaknili tudi vprašanja proaktivnosti pedagoga in andragoga $\mathrm{v}$ raziskovanju čustvenega doživljanja v kontekstu lastnega pedagoškega/ andragoškega dela.

Tretjo skupino z naslovom Vzgoja $v$ času pandemije zahteva izgradnjo inovativnih učnih okolij - primer vzgoje z umetnostjo je moderiral dr. Robi Kroflič. V okviru diskusijske delavnice so besedo dobile pedagoginje in pedagogi z različnih vzgojno-izobraževalnih institucij, ki so $\mathrm{z}$ otroki in mladostniki tudi v času šolanja na daljavo izvajali dejavnosti vzgoje z umetnostjo. Primere dobre prakse so predstavili predstavniki iz Dijaškega doma Ivana Cankarja, Srednje zdravstvene šole Slovenj Gradec in Gimnazije Ljutomer. Vse te vzgojno-izobraževalne institucije so tudi del projekta SKUM. Udeleženci diskusijske skupine so se strinjali, da so tovrstni projekti v šolski praksi vsekakor dobrodošli, a hkrati poudarili, da se lahko učitelj avtonomno odloča in v okviru svojega predmeta vsebine poveže $\mathrm{z}$ aktualnimi dogajanji $\mathrm{v}$ družbi ter s tem spodbuja aktivno in kritično državljansko držo posameznika.

PAD 2021 se je sklenil s fotografsko razstavo Mateja Peljhana z naslovom Covid-19: misliti z umetnostjo v galeriji Peti štuk v petem nadstropju Filozofske fakultete. Razstava je na ogled od 14. septembra do 14. oktobra 2021. Fotograf Matej Peljhan je po poklicu klinični psiholog in je v okviru razstave prikazal različne probleme, vprašanja, dileme in strahove, s katerimi smo se srečevali v času pandemije covida-19. S pomočjo svojih družinskih članov in različnimi domačimi pripomočki je ustvaril zanimive fotografije, ki opisujejo doživljanje pandemije covida-19.

Sklenemo lahko, da je imel čas pandemije covida-19 močan vpliv na vse pedagoge in andragoge. Izmenjava teoretičnih pogledov in ugotovitev iz raziskav, ki smo jih v okviru diskusijskih skupin dopolnili še s primeri iz prakse, je pokazala, da prav nihče ni ostal ravnodušen. V ospredje so bili postavljeni različni problemi na štirih ravneh: 
- osebni problemi (način doživljanja sebe znotraj osebne psihološke perspektive, soočanje z različnimi ovirami: nizke predstave o sebi in zmožnostih za učenje, nizka pričakovanja, nezmožnost soočanja $z$ nepredvidljivimi težavami, strah in izogibanje tveganju idr.),

- situacijski problemi (način dela oz. vzgoje in izobraževanja na daljavo, težave pri spretnosti ločevanja delovnega od zasebnega okolja idr.),

- širši institucionalni problemi (s perspektive socialne konstrukcije, povezovanja s kolegi, vodstvom institucije),

- družbeni problemi (pod vplivom ustavljenega javnega življenja in soočanja s postresničnostjo, lažnimi novicami in teorijami zarot).

Izkazalo se je, kako aktualna in pomembna je bila tematika letošnjih PAD, saj smo lahko tako kritično osvetlili in razmislili, kako smo v formalnem in neformalnem izobraževanju z otroki, mladimi in odraslimi učenci doživljali to obdobje, kaj smo se iz tega obdobja lahko naučili in kaj je smiselno ohraniti tudi, ko se bosta življenje in delo dokončno vrnili v ustaljene tirnice. Gotovo pa je bil spremenjen način dela priložnost za razvoj spretnosti poučevanja na daljavo in za pridobitev širših informacijsko-komunikacijskih spretnosti.

Hkrati smo ugotovili, da je nujen tudi nadaljnji razmislek o okrepitvi izobraževalnega in emancipatornega potenciala informacijsko-komunikacijske tehnologije v izobraževanju. Smiselno je, da bi vodstva šol in izobraževalnih institucij čimprej analizirala nevralgične točke iz časa epidemije covida-19 in si postavila nove cilje ter tako prispevala k dvigu kakovosti vzgoje in izobraževanja. Pri tem bi tudi država morala nameniti več sredstev za usposabljanje učiteljev in za razvoj možnosti kombiniranih oblik dela v šolah in drugih izobraževalnih institucijah (tudi za odrasle), kjer je to seveda možno in smiselno.

Izkušnja covida-19 nas je pretresla, hkrati pa opogumila in obogatila v zavedanju, da je pomembna motivacija vseh za vseživljenjsko učenje in izobraževanje zlasti na področju informacijsko- komunikacijske tehnologije. Zavedamo se, da so za razvoj kariere pedagogov in andragogov pomembni prav medsebojno zaupanje, kolegialna podpora drug drugemu ter prava mera strokovnih izzivov, ki vodijo v kakovostnejši osebni in profesionalni razvoj, s tem pa v kakovostnejšo vzgojo in izobraževanje. 